Годишњак Филозофског факултета у Новом Саду, Књига ХХХVII (2012)

Слађана Зуковић, Јасмина Клеменовић

УДК 37.017.92/.93

Филозофски факултет Универзитета у Новом Саду

$37: 316.7$

sladjanaz@ff.uns.ac.rs

Оригиналан научни рад

\title{
ОБАВЕЗНИ ИЗБОРНИ ПРЕДМЕТИ У ШКОЛИ И РАЗВОЈ ДЕМОКРАТСКИХ ВРЕДНОСТИ ${ }^{1}$
}

\begin{abstract}
Рад почива на становишту да је школски контекст важан ослонац у прихватању и усвајању демократских и универзалних вредности заједнице. У том светлу разматран је смисао демократизације савременог образовања и увођења обавезних изборних предмета у школски систем. Сходно томе, анализиране су могућности и претпоставке утицаја Верске наставе и наставе Грађанског васпитања на развој националног и културног идентитета и проевропских вредности (људска права и интеркултурализам), као начина превазилажења модела „традиција или савременост“ моделом „традиција и савременост“. Изнете теоријске поставке поткрепљене су и резултатима емпиријских истраживања која се односе на анализу ефеката реализације наставе поменутих предмета на средњошколском нивоу образовања, с посебним освртом на испитивање ставова полазника обавезно изборних предмета према универзалним вредностима.

Кључне речи: Верска настава, Грађанско васпитање, демократизација образовања, интеркултурализам, универзалне вредности.
\end{abstract}

\section{УВОД}

Значајни проблеми неједнакости и поларизације света захтевају систематске промене у приступу образовању и спремност да се прихвате нове вредности које ће усмеравати образовну политику и праксу. Отуда се у релевантној литератури (Moss 2008) као кључне вредности новог образовања издвајају демократија, критичко мишљење, релациона етика, креативност, социјална правда и солидарност. Ове вредности се разумеју као основа за реорганизовање образовних институција које треба да постану доступне свима,

1 Рад је настао у оквиру научно-истраживачких активности на пројекту Педагошки плурализам као основа стратегије образовања (179036) који у периоду 2011-2014. године финансира Министарство за науку и технолошки развој Републике Србије. 
да представљају место сусретања деце, младих и одраслих који живе и уче заједнички кроз свакодневну интеракцију, дијалог, међусобно упознавање и уважавање.

Процес реорганизације система и процеса образовања којим се омогућава досезање поменутих вредности означава се као процес демократизачије образоваға (Хавелка 2000) и који се очитује кроз сферу спољашњих и унутрашњних промена. Спољашња демократизација образовања подразумева ангажман друштвене заједнице у развијању и подржавању система који ће обезбедити једнаку доступност образовања свима који желе и који су способни да уче и образују се. Унутрашња демократизација образовања односи се на управљање системом, као и на програмску флексибилност. Демократизација процеса одлучивања огледа у стварању могућности да сви актери образовног процеса одлучују о одређеним питањима из домена својих активности, док програмска флексибилност подразумева могућност ученика да у понуђеним оквирима бирају активности у којима ће учествовати, као и да утичу на стварање нових и другачијих прилика за ангажовање (Ибид: 20).

У суштини, основу демократизације образовања чини настојање да се образовни процес учини флексибилнијим и диферециранијим и на тај начин у већој мери усклађен са притисцима модерног живота који захтева да млади људи буду спремни на многоструке животне и професионалне улоге, те вољни да партиципирају у конструисању праведне државе која би рефлектовала демократске вредности (Милутиновић 2008). Како би се ученицима омогућило да током образовања откривају и прихватају демократске вредности, поред обавезне, академски оријентисане наставе, у савременим школама се све већа важност даје изборној и факултативној настави.

\section{ИЗБОРНИ ПРЕДМЕТИ У ЖИЖИ ДЕМОКРАТИЗАЦИЈЕ ОБРАЗОВАЬА}

Иако факултативна и изборна настава у школској пракси нису новост оне се данас виде као незамењив простор за бављење актуелним питањима и проблемима заједнице, те прилика за унапређивање личног и друштвеног развоја ученика (Вујић 2002). Оба вида наставе могу да се изводе у различитим облицима: изборни предмети, изборни програми у оквиру једног предмета, изборни пројекти или практични радови, али и као пракса укрштања програма. 
Међутим, док је основно начело факултативне наставе добровољност и слободно опредељење, за изборну наставу је важно да су ученици обавезни да се определе између одређеног броја понуђених изборних предмета које затим редовно похађају.

Са нивоом образовања повећава се и значај и улога изборне наставе. Као изборни предмети у европским школама на нивоу основног образовања јављају се религијско образовање, етика, друштвене и културне студије, настава страних језика, а у виду укрштених приступа програми грађанског, глобалног и медијског образовања. На средњошколском нивоу поред изборних предмета који се баве анализом и дискусијом различитих аспеката друштвеног и културног живота, те наставе страних језика или информатичке писмености и рачунарства, као изборни предмети јављају се продубљени ранији обавезни предмети (музика, уметност, историја, географија, биологија, технологија и сл.) или се организују курсеви утемељени на новим методама и приступима у настави (медији, фотографија, филм, драма, музика, плетење, рад са дрветом и металом, домаћинство, професионална оријентација и други које предлажу школа и локална заједница) (Ибид).

У изборним предметима усмереним на анализу друштвених и културних питања посебна пажња посвећује се демократским процедурама учествовања у заједничким активностима као што су расправе, слободно изражавање мишљења и доношење одлука. Акценат се ставља и на развој способности рефлексије, вођења дијалога и аргументовања на којима почивају процеси вредновања и критичког мишљења који захтевају и способност сталне измене перспектива (Moss 2007). Истовремено, предвиђа се усклађивање изборне наставе са европском димензијом образовања која подразумева интеркултурални приступ у настави и оспособљавање младих за међународну културну сарадњу. То подразумева да се наставним радом ученици усмеравају на сусрет с другим националностима, језицима, културама, расама и религијама претварајући их у вредности и доприносећи обостраном обогаћивању (Зуковић, Клеменовић и Будић 2010). Идеја је да се код младих формирају ставови и вредности, развије начин опхођења са другим културама, успостави толеранција и поштовање историје и начина живота других људи и нација. Овакав приступ подразумева познавање демократских процедура, поштовање принципа демократске 
комуникације путем дијалога и дебата, чиме се врши припрема ученика за активан живот у грађанском демократском друштву.

Представљени процеси демократизације образовања интензивирани су током последње деценије и у систему образовања и васпитања Републике Србије. У том смислу, покренут је процес унутрашње демократицазије образовања и то кроз аспект дивезификације рада у школи која је омогућила увођење наставних садржаја, метода и циљева који уважавају различите могућности и интересовања ученика. Уместо ранијег јединственог програма конципиран је оквирни национални план и програм који школе реализију кроз три вида програма: обавезни, изборни и факултативни (Максић и Шевкушић 2007).

Када је реч о факултативном програму, значајно је нагласити да његова реализација подразумева задовољавање интересовања ученика у складу са могућностима школе. Међутим, када је реч о изборном програму, уведен је модел који подразумева да школе свих нивоа образовања добијају обавезу да као један од изборних предмета понуде алтернативе - Верска настава или Грађанско васпитање, док се за други изборни предмет ученици одлучују бирајући још један предмет према својим склоностима. Листа изборних предмета за основне школе обухвата: лепо писање, народну традицију, руке у тесту-откривање света, чувари природе, од играчке до рачунара, шах, матерњи језик са елементима националне културе, страни језик, основи информатике и рачунарства, домаћинство. Изборни предмети се изучавају по један час недељно изузев матерњег језика са елементима националне културе и страног језика који се изучавају по два часа недељно. На нивоу средњег образовања у наставним плановима и програмима различитих типова школа предвиђена су два обавезно изборна предмета од којих један подразумева опредељење за Верску наставу или Грађанско васпитање, док се други предмет бира из групе стручних предмета који продубљују одређену област или општих предмета који доприносе изграђивању личне културе. Листа предмета за други изборни предмет који су обавезне да организују средње школе није коначна и може се допунити на предлог школе програмом који предходно одобри надлежно министарство. 


\section{ВЕРСКА НАСТАВА И ГРАЪАНСКО ВАСПИТАЮЕ КАО ОБАВЕЗНИ ИЗБОРНИ ПРЕДМЕТИ У ОБРАЗОВНОМ СИСТЕМУ СРБИЈЕ}

Као што је већ поменуто, у образовном систему Републике Србије, предмети Верска настава и Грађанско васпитање имају статус обавезног изборног предмета, што значи да ученици и основних и средњих школа имају обавезу да се определе за похађање једног од ова два предмета, при чему је ученицима омогућено да током истог образованог циклуса промене свој првобитни избор. Одлука за овакав реформски подухват, подстакнута је, између осталог, тежњом да овакав вид демократизације образовања буде усклађен са општим тенденцијама развоја европске димензије образовања.

Верска настава је у наш образовни систем уведена као предмет са конфесионалним обележјем. У оквиру званичних докумената (Службени гласник РС - Просветни гласник, бр. 5/2001; бр. 4/2003) истиче се да је циљ Верске наставе упознавање ученика са вером и духовним искуством сопствене, историјски дате Цркве или верске заједнице, као и потреба отвореног и толерантног дијалога и уважавања других религијских искустава, научних сазнања, филозофских погледа и свих позитивних искустава и достигнућа човечанства. Такође се истиче циљ изградње социјалних односа између ученика и формирање еколошке свести. Основни задаци Верске наставе су да ученицима пружи целовити религијски поглед на свет и живот, да систематски упознају своју веру у њеној доктриналној, литургијској, социјалној и мисионарској димензији, а све то у духу толерантног односа према другим религијама, прихватајући сва позитивна искуства људи без обзира на њихову националну припадност и верско опредељење. Остваривање поменутих задатака треба да се спроводи како на информатино-сазнајном, тако и на доживљајном и делатном плану, што отвара могућност да се на систематски начин усмерава развој верског става. Овако конципиран модел Верске наставе, поред пружања знања о вери, треба да омогући младим људима да критички просуђују о властитом животу и свим проблемима и питањима друштва и света у коме живе (Кубурић, Зуковић 2010).

Када је реч о предмету Грађанско васпитање, у званичним документима (Службени гласник РС - Просветни гласник, бр. 5/2001) као основни циљ реализације садржаја овог предмета истиче се потреба да ученици стекну знања, 
развијају способности и вештине и усвоје вредности које су предпоставка за целовит развој личности и за компетентан, одговоран и ангажован живот у савременом грађанском друштву у духу поштовања људских права и основних слобода, мира, толеранције, равноправности полова, разумевања и пријатељства међу народима, етничким, националним и верским групама. Анализа допуна правилника који су уследили (Службени гласник РС - Просветни гласник, br.5/2003; br.11/2005) показује да је постепено дошло до проширивања тема и померања наставних садржаја чиме се Грађанско васпитање у средњој школи приближило питањима грађанског активизма и образовању за демократију, а наставницима се сугерише да наставни процес у разреду током целе године остварују у складу са оним што се учи, изграђујући демократску атмосферу и поштовање права ученика. Као основни методски приступ у извођењу наставе Грађанског васпитања препоручује се радионичарски начин рада, док се међу облицима рада издвајају: симултана индивидуална активност, рад у паровима или малим групама, размена и разговор у кругу, групна дискусија и излагање пред целом групом.

Имајућу у виду садржаје који се презентују путем Верске наставе и наставе Грађанског васпитања може се закључити да је реч о предметима који су утемељени на различитим вредносним системима. Ипак, чини се да, иако са различитих основа, оба предмета имају значајан потенцијал за развој проевропских демократских вредности и културног идентитета младих, што отвара простор за интеркултурално васпитање и образовање кроз процесе изградње, поштовања и јачања културног плурализма и толеранције.

\section{ПОХАЂАЊЕ ОБАВЕЗНИХ ИЗБОРНИХ ПРЕДМЕТА У ФУНКЦИЈИ РАЗВОЈА ДЕМОКРАТСКИХ ВРЕДНОСТИ}

Досадашња искуства у реализацији наставе предмета Грађанско васпитање (Бауцал и сар. 2009; Ђуришић-Бојановић 2006) показују да ученици током васпитно-образовног процеса истовремено изграђују самопоштовање и стичу компетенције неопходне за суживот са различитим културама. Њима се нуди прилика да развијају способности конструктивне комуникације, толеранције на различите погледе и понашања, свест о индивидуалној и колективној одговорности, разумевање националног и културолошког 
идентитета у интеракцији са културолошким идентитетом Европе и остатка света и др. Такође, креатори европске образовне политике препознали су значај наставе религије (без обзира да ли се реализује као конфесионална, мултиконфесионална или неконфесионална) за интеркултурално васпитање и образовање и успостављање интерелигијског дијалога. Притом се наглашава да учење за различитост и учење за заједнички интерес треба посматрати као модел у којем партикуларно и универзално могу равноправно да егзистирају (Hasall \& Roebben 2006: 448). Суштина је у тежњи да се створе услови за разумевање и прихватање различитости путем усвајања религијских вредности које ће бити у позитивној корелацији са принципима толеранције, плурализма и мултикултурализма. У светлу наведених аргумената чини се оправданим очекивање да оба предмета буду у функцији демократизације образовања, у функцији обликовања школске заједнице као микрокозма отвореног друштва (Kodelja \& Bassler 2004), а самим тим и у функцији развоја општих демократских вредности.

Поменута очекивања разматрана су и путем истраживања која су ауторке овог рада реализовале у протеклих неколико година, а која су била усмерена на испитивање различитих аспеката наставе ових предмета на средњошколском нивоу. У том смислу значајно је указати на резултате истраживања (Клеменовић и Лазић 2007; Клеменовић 2009) која су се односила на анализу остварености циљева и задатака, као и процену релевантности програмског пакета наставе Грађанског васпитања од стране наставника. Наставници су истакли да су садржаји из домена људских права и права детета сувопарни, оптерећени сувишним понављањима те неадекватним методичким поступцима и сценаријима радионица који нису примерени средњошколцима. Као проблем у практичном раду наставници су издвојили и превелик број часова за планирање акције у корист права. Осим што се овом активношћу сужава тематика и ремети динамика васпитно-образовног процеса, она често и не може да се спроведе до краја јер ученици не поседују потребна знања и вештине нити показују потребну зрелост. Отуда наставници предлажу иновирање методичких поступака, увођење нових тема и промену статуса предмета. Известан број њих је истакао важност вредновања целокупног залагања ученика као и потребу оцењивања знања из овог предмета како би се ојачали укупни васпитно-образовни ефекти. 
Део проблема у реализацији циљева наставе Грађанског васпитања наставници су препознали и у специфичној клими локалних заједница које не показују осетљивост и разумевање за потребе и активизам младих. Из тих разлога, испитаници су истакли да је демократско образовање и оспособљавање за парципативно учење потребно свим наставницима у школи и да представља предуслов демократизације образовног система. Значајну препреку у превазилажењу формализма и традиционално схваћеног образовања представља чињеница да наставни кадар, нарочито у средњим стручним школама, поред стручних компетенција нема одговарајућа педагошко-психолошка знања и дидактичко-методичке вештине потребне за рад са младима и у интерактивној настави.

У истраживању које се односило на испитивање мишљења средњошколаца и њихових родитеља о реализацији и ефектима наставе Грађанског васпитања (Зуковић, 2009а) утврђено је да већина испитаника сматра да млади могу имати велике користи од похађања овог предмета, али и да његови потенцијали нису довољно искоришћени у пракси. Четвртина испитаних средњошколаца није сигурно да ли се неке промене у њиховом понашању могу приписати утицајима наставе Грађанског васпитања, а готово половина ученика и њихових родитеља процењује да досадашње похађање овог предмета није утицало на промену њиховог понашања нити је значајније деловало на њихов развој. Ипак, није занемарљив број испитаника (скоро четвртина испитаних средњошколаца и њихових родитеља) који процењује да је похађање наставе Грађанског васпитања имало позитивне ефекте на развој и понашање ученика, пре свега у домену унапређивања комуникације и зрелијег, тј. реалнијег сагледавања себе и других.

Када је реч о Верској настави, значајно је истаћи резултате истраживања (Зуковић, 2009б) које је било усмерено на анализу очекиваних и опажених ефеката похађања овог предмета од стране средњошколаца и њихових родитеља. Показало се да је најчешћи мотив ученика за избор овог предмета било религијско опредељење и интересовање за ову област, подстакнуто жељом за новим сазнањима и очекивањем позитивног утицаја на личност. Највећи број и ученика и њихових родитеља процењује да је похађање Верске наставе допринело бољем познавању вере, културе и традиције сопственог народа. 
Такође, испитаници истичу да позитивни ефекти видљиви на пољу моралног развоја личности, система вредности и нивоа религиозности. Добијени подаци су показали да су опажени ефекти (нова сазнања, развој религиозности, позитивне промене у понашању и личности ученика итд.) били у складу са разлозима опредељења за овај предмет, те да су очекивања испитаника у значајној мери испуњена. Ипак, не треба пренебрегнути ни чињеницу да, према налазима овог истраживања, значајан број испитаника (22\% ученика и 26,95 родитеља) није опазио никакве ефекте похађања овог предмета, што наводи на закључак да школска веронаука има велики васпитни потенцијал, али да тај потенцијал није у потпуности искоришћен.

Поред истраживања мишљења ученика и родитеља о Верској настави, значајно је указати и на истраживање (Зуковић, 2006) чији су узорак чинили вероучитељи и стручни сарадници - педагози. На основу добијених налаза изведен је закључак да, поред чињенице да је Верска настава заузела своје место у школском систему, треба имати у виду и чињеницу да су у процесу реализације овог школског предмета присутне и одређене потешкоће: проблеми техничке и организационе природе, недостатак кадрова, недовољна педагошкодидактичко-методичка оспособљеност вероучитеља, неадекватни уџбеници и садржаји који нису у довољној мери прилагођени дечјем узрасту и њиховом познавању материје.

Веома индикативан налаз поменутог истраживања односио се на став испитаника о потреби превазилажења ривалства и антагонизма између Верске наставе и Грађанског васпитања, јер су ови предмети постављени као алтернативе које се искључују, иако, имајући у виду сврху њиховог увођења у школе, то не би требало да буду. У прилог томе говоре и налази истраживања (Матић 2010, према: Клеменовић и Зуковић 2011) које је било усмерено на испитивање односа полазника Верске наставе и Грађанског васпитања према универзалним вредностима. За потребе истраживања коришћен је Упитник вредности - CBC (Schwartz Value Survey) који је заснован на Шварцовој теорији о универзалним вредностима. Истраживање је обављено на узорку од 118 средњошколаца, од чега је 53 испитаника похађало Верску наставу, а 65 испитаника је похађало Грађанско васпитање. Осим генералног налаза који се односи на чињеницу да су средњошколци показали позитиван однос према 
свим мереним универзалним вредностима, посебно је важно истаћи налаз о томе да у овом истраживању нису утврђене статистички значајне разлике на основу којих би се могло тврдити да је похађање једног од обавезно изборних предмета повезано са проценом значаја универзалних вредности. Наиме, утврђено је да полазници и Верске наставе и Грађанског васпитања позитивно и високо вреднују и оне универзалне вредности за које би се могло рећи да нису у складу са вредносним циљевима експлицитно или имплицитно садржаним у наставним програмима ових предмета. Тако су полазници Грађанског васпитања позитивно оценили универзалне вредности Традиција и Конформизам, док су полазници Верске наставе показали позитиван однос према вредностима Постигнуће и Самоусмерење. На основу оваквих налаза могуће је констатовати да су полазници Грађанског васпитања отворени за прихватање и поштовање културних и верских обичаја и идеја. С друге стране, полазници Верске наставе су позитивно усмерени ка жељи за успехом - дефинисаним друштвеним стандардом, иако, изборни предмет чију наставу похађају, већи акценат ставља на ,унутрашњи духовни успех“. Укратко речено, резултати добијени путем овог истраживања указују на неоправданост, веома често присутног, супротстављања Верске наставе и Грађанског васпитања, те импликују потребу промишљања и трагања за „додирним тачакама“ у реализацији наставе ових обавезно изборних предмета.

\section{ЗАКЉУЧНА РАЗМАТРАЬА}

Анализа могућности и претпоставки развоја демократских вредности путем образовања, посебно када је реч о доприносу наставних предмета чији се садржаји и методе, на известан начин, виде као супротстављени - какав је случај са предметима Грађанско васпитање и Верска настава, показује да је унапређивање квалитета наставне праксе у овој области могуће постићи креирањем услова за отворен и толерантан дијалог који би био основа за размену личних искустава, ставова и мишљења. Овакав приступ може допринети да се досадашњи модел „савременост или традиција“ замени моделом „савременост и традиција“. Такође, простор сусретања, природног подударања и прожимања хришћанских (духовних) вредности са демократским (европским) вредностима јесте простор за демократизацију школе у целини, што у крајњој инстаци, за 
ефекат треба да има лакше функционисање младих у свету различитости.

Имајући у виду да су обавезни изборни предмети уведени са намером да допринесу личном и друштвеном развоју ученика, кроз задовољавање специфичних потреба и интересовања младих који уче за живот у глобалном свету, важно је наставити са њиховим методичким и садржинским иновирањем. Такође, у овом сегменту наставе ученицима треба пружити могућност да, поред до сада понуђених садржаја везаних за област моралног, правног, политичког и културног освешћивања, стекну и широк круг компетенција из неких других области непроцењивих за социјални развој младих какве су: здравстено васпитање, породично образовање, медијско образовање, образовање за мир, глобално образовање, образовање за одрживи развој итд.

На крају, не сме се изгубити из вида да су темељне вредности и основ демократизације садржани најпре у свакодневном животу школе - односима између наставе и школских прописа и правила, школске културе и окружења, као и образовне филозофије које се школа придржава. Кључ ове сложене мреже социјалних и културних релација представљају наставници и друго стручно особље школе чије компетенције морају одговорити на захтеве усаглашавања национално и интернационално прихваћених вредности.

\section{ЛИТЕРАТУРА}

Бауцал, А. и сар. (2009). Процена ефеката грађанског васпитања. Београд: Грађанске иницијативе.

Вујић, И. (2002). Примери изборне и факултативне наставе у неколико европских земаља, Настава и васпитање, Vol. 51, No.3: 248-261.

Ђуришић-Бојановић, М., (2006). Ставови младих према интеркултуралности и прихватање плураритета идеја, Зборник Института за педагошка истраживања, Vol. 38, No. 2: 430-444.

Зуковић, С. (2006). Реализација верске наставе у школама - стање, проблеми и могућности, У: Е. Каменов (уред.) Реформа система васпитаға и образовања у Републици Србији, (279-292). Нови Сад: Филозофски факултет.

Зуковић, С. (2009а). О грађанском васпитању у средњој школи из перспективе ученика и родитеља, Tеме, Vol. 33, No.4: 1353- 1368. 
Зуковић, С. (2009б). Верска настава у средњој школи из перспективе ученика и родитеља, Настава и васпитање, Vol. 58, No.3: 348-361.

Зуковић, С., Клеменовић, Ј., Будић, С. (2010). Школа у функцији развоја интеркултурализма, У: Љ. Суботић и И. Живанчевић-Секеруш (уред.) Сусрет култура, Зборник радова са 5. међународног интердисциплинарног симпозијума, Књига 1, (193-198). Нови Сад: Филозофски факултет,

Клеменовић, J. (2009). Образовање за људска права у систему средњошколског образовања у Србији. Теме, Vol. 33, No.4: 1303-1318.

Клеменовић, Ј., Лазић, С. (2007). Образовање за људска права у нашој школи. У: О. Гајић (уред.) Европске димензије промена образовног система y Србији - Систем образовања у Србији у вертикали европских вредности, Зборник радова, Књига 3 (39-53). Нови Сад: Филозофски факултет, Одсек за педагогију.

Клеменовић, Ј., Зуковић, С. (2011). Допринос обавезно изборних предмета у школи развоју националног и културног идентитета и проевропских вредности. У:Школакао чинилачразвоја националноги иултурногидентитетаи проевропских вредности: Образоваъе и васпитағе - традииија и савременост, Зборник резимеа, стр. 113. Јагодина: Педагошки факултет у Јагодини.

Kodelja, Z., Bassler, T. (2004). Религија и школовање у отвореном друштву (оквир за информални дијалог), Љубљана.

Кубурић, 3., Зуковић, С. (2010). Верска настава у школи. Нови Сад: ЦЕИР, Савез педагошких друштава Војводине.

Максић, С., Шевкушић, С. (2007). Припрема наставника за реализацију изборних предмета, Настава и васпитање, Vol. 56, No.2: 162-173.

Милутиновић, J. (2008). Циљеви образовања и учења у светлу доминантних теорија васпитања 20. века. Нови Сад: Савез педагошких друштава Војводине.

Moss, P. (2007). Bringing politics into the nursery: Early childhood education as a democratic practice. Working Paper 43. The Hage: Bernard van Leer Foundation.

Moss, P. (2008). Toward a New Public Education: Making Globalization Work for Us All. Child Development Perspectives, Vol.2, No.2: 114-119.

Службени гласник Републике Србије -Просветни гласник, 2001, бр. 5.

Службени гласник Републике Србије -Просветни гласник, 2003, бр. 4. 
Службени гласник Републике Србије-Просветни гласник, 2003, бр. 5.

Службени гласник Републике Србије-Просветни гласник, 2005, бр. 11.

Хавелка, Н. (2000). Ученик и наставник у образованом проиесу. Београд: Завод за уџбенике и наставна средства.

Hasall, A., Roebben, B. (2006). Intercultural and interfaith dialogue through education, Religious Education, Vol. 101, No. 4: 443-452.

Sladjana Zuković i Jasmina Klemenović

\title{
COMPULSORY ELECTIVE SUBJECTS INTO THE SCHOOL AND DEVELOPMENT OF DEMOCRATIC VALUES
}

\begin{abstract}
Summary
The paper is based on the standpoint that the school context is an important pillar in the acceptance and adoption of democratic and universal values of the community. In that sense, there has been analyzed a meaning of democratization of the contemporary education and an introduction of compulsory elective subjects into the school system. Accordingly, there have been analyzed possibilities and assumptions of the influence of both Religious instruction and Civic education instruction on the development of national and cultural identity and proEuropean values (interculturalism and human rights), as a way for overcoming the model of "tradition or modernity" with the model "tradition and modernity." Presented theoretical assumptions are supported by the results of empirical researches regarding the analysis of effects of the teaching implementation of the subjects at the secondary school level of education, with special emphasis on examining the attitudes of pupils who attend compulsory elective subjects towards the universal values.
\end{abstract}

Key words: Religious instruction, Civic education, democratization of education, interculturalism, universal values. 